\title{
ON THE NATURE AND INCIDENCE OF GOITRE IN FINNISH DAIRY CALF POPULATION
}

\author{
Vappu Kossila, Ulla-Rittta Lehtonen, Maija-Leena Sulkinoja \\ and Ritva MyllymaA \\ Department of Animal Husbandry, University of Helsinki
}

Received February 9, 1970

Iodine prophylaxis has been proved beneficial in preventing goitre in man and domestic animals. Yet there are many geographic areas in which the incidence of goitre is significantly higher if compared to some others. Apparently, either the amounts of iodine that have been used, have not been sufficiently high, or there are other regional factors, viz. goitrogens, water pollution, depletion of trace minerals from the soil as a result of intensive cultivation, which are involved.

The purpose of this study was to investigate whether, and to what extent, goitrous thyroids could be found in dairy cattle population born and raised in different areas of Finland, and to verify the prevailing histological characteristics of the respective thyroids. Since the geographic distribution of goitre in cattle seems to be positively correlated with that in man (Wiertz 1957, Stukowsky et al. 1960, Bobek \& Pelczarska 1963, Brand et al. 1963), the results of this study may also be of interest from the human point of view.

\section{Material and methods}

During 25. 1.-19. 4. 1968, altogether 1124 thyroid gland samples were collected from calves and young cattle brought into the slaughteries of 16 different cities located in various parts of Finland. The source of the material comprised about $60 \%$ of the rural counties of the country. Collection of the samples was begun in the southern parts of Finland moving northwards. Breed, sex, carcass weight, and the exact location, in which the animal was born and raised, were recorded for each case.

The thyroid material, obtained from the dairy herd of the Viik Experimental Farm during iodine prophylaxis in 1960 - 69 (KossiLA 1967, Kossil. 1969), serves as a control material for this study. The said farm is located in area 17 (Table 3) within the boundaries of the city of Helsinki. 

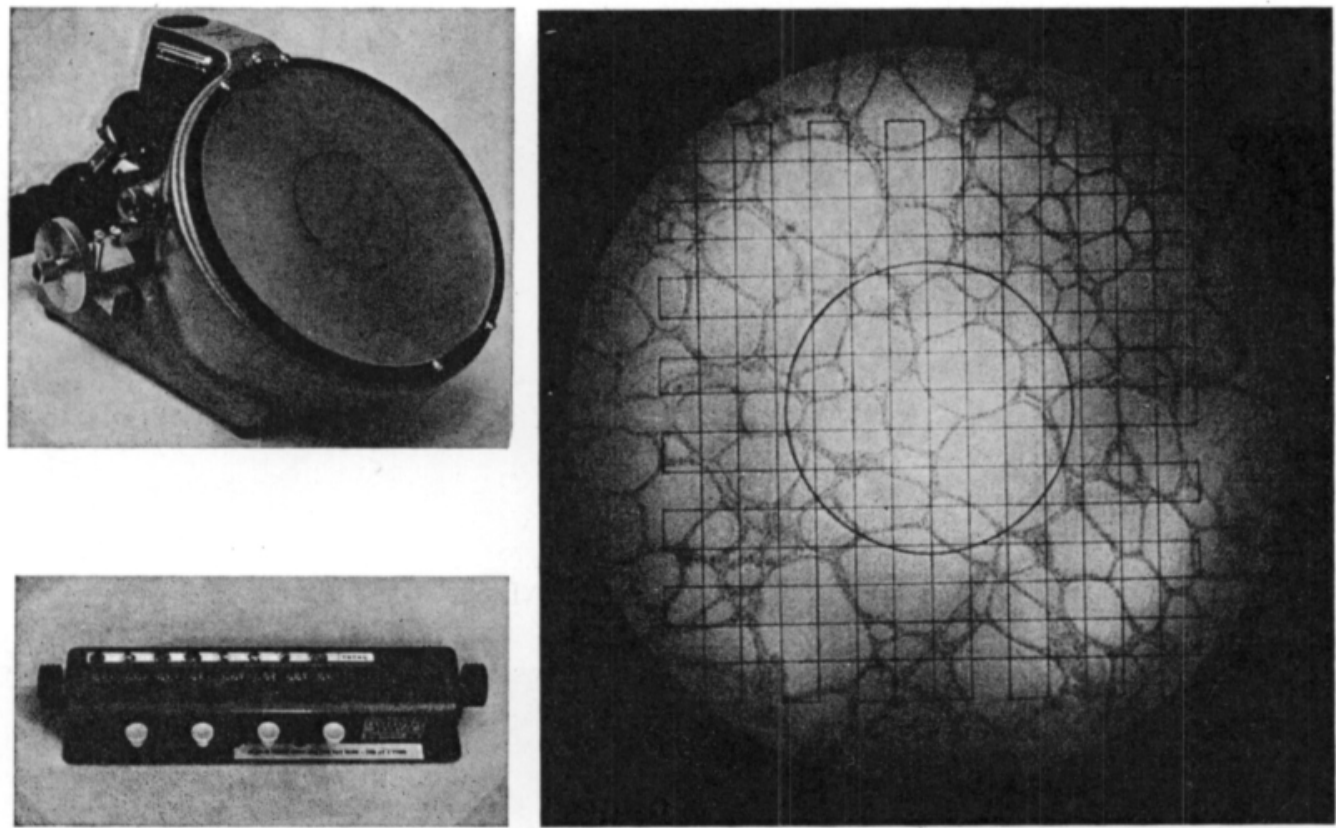

Fig. 1. Equipment used in the histometric measurements. Up on the left lanameter. Below on the left blood cell counter. On the right the network attached to the lanameter.

The thyroid glands were weighed and handled as previously described (KossiLA 1967, p. 36). Tissue preparations were made in the laboratories of the Department of Forensic Medicine, University of Helsinki and the Department of Pathology, College of Veterinary Medicine, Helsinki. The stains of Weigert van Gieson and hematoxylin-eosin were used.

Several histological parameters were considered in the investigations of the morphological characteristics of the thyroids.

The follicular number (FN), an index of the follicular size, was determined from ten systematically selected fields of vision with constant magnification $(x 125)$ by lanameter (Fig. 1). The number of thyroidal follicles found within the inner circle (diameter $7.5 \mathrm{~cm}$ ) of the lanameter's light table, were calculated by applying the following principles: a follicle of which definitely less than one half was inside the inner circle was not counted, a follicle of which definitely more than half was inside the inner circle was counted as one, two such follicles of which about one half was inside the inner circle were considered as one. A large numerical value of $\mathrm{FN}$ indicates that the follicles are small and vice versa.

E pithelial cell height $(\mathrm{E} \mu)$, an index of the intensity of the thyrotropic hormone (TSH) stimulation on the thyroid, was measured from the same areas of the tissue preparations than the FN and from such parts of the follicular epithelium which represented more or less the mean cell height of the particular area under observation.

$\mathrm{Histological} \mathrm{activity.} \mathrm{The} \mathrm{thyroid} \mathrm{preparations} \mathrm{were} \mathrm{first} \mathrm{thoroughly}$ crossexamined with a light microscope, after which they were classified, according to 

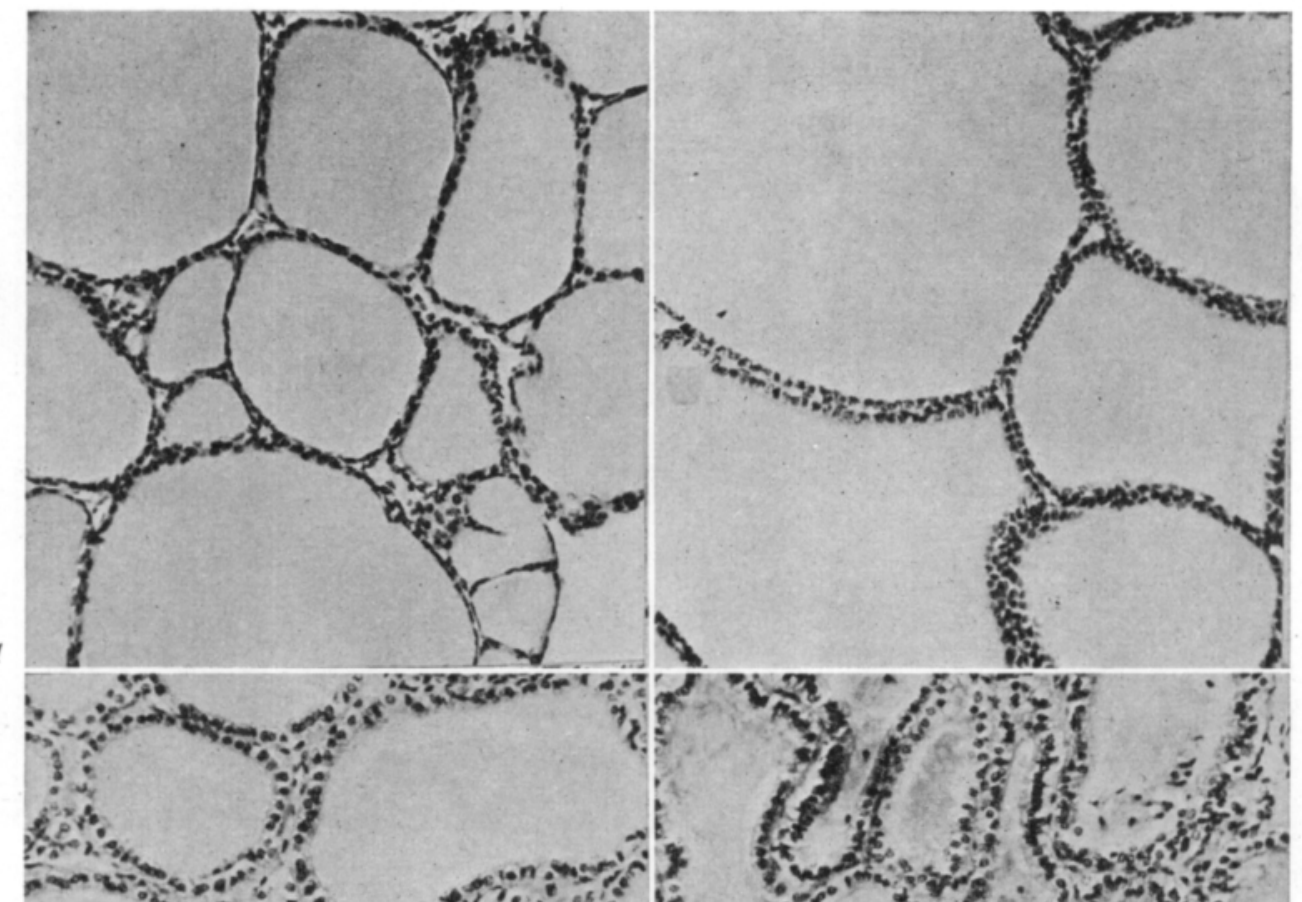
par

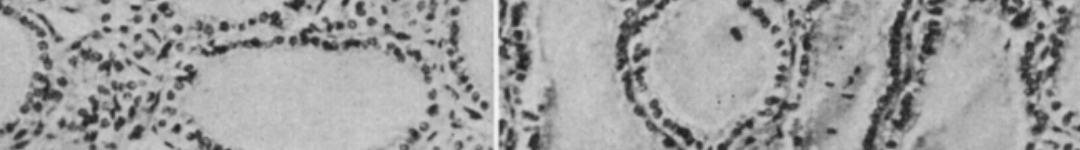

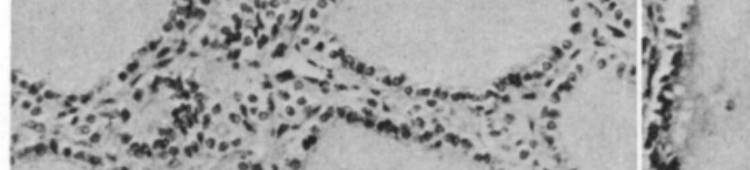

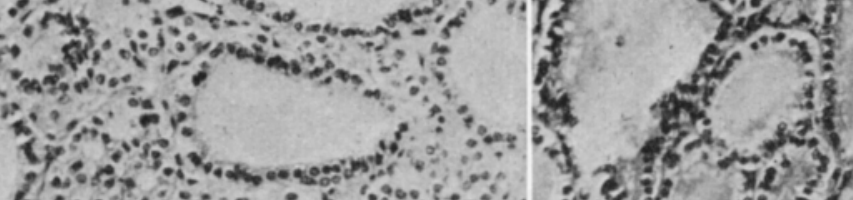

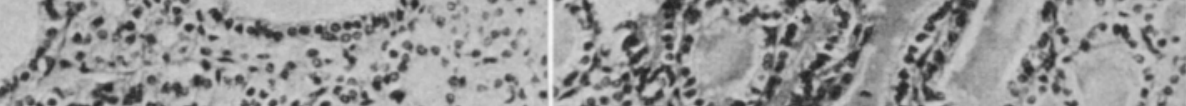

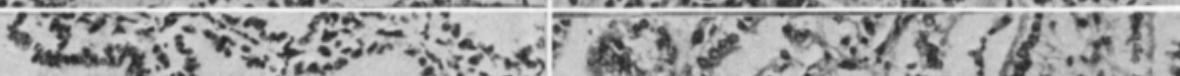
E. सें xye

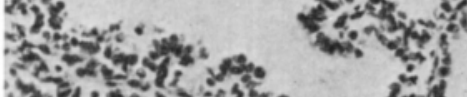


6.5. 3.

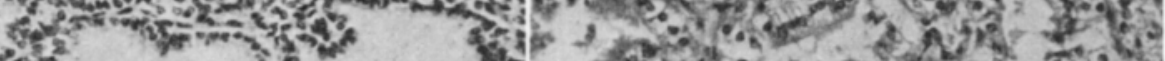
5.7.



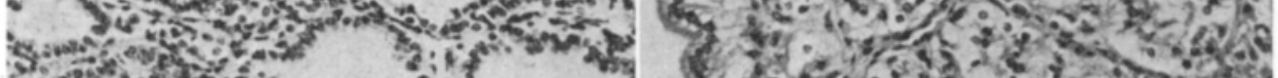

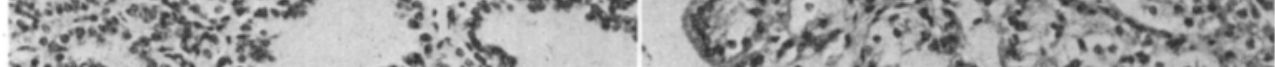

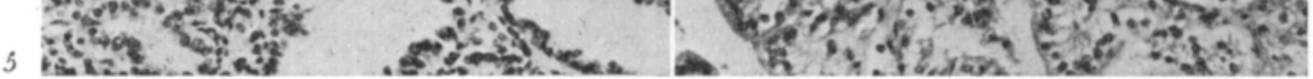


Table 1. Histological classification of the thyroids according to certain prevailing morphological characteristics of the gland.

\begin{tabular}{|c|c|c|c|c|c|}
\hline \multirow{2}{*}{$\begin{array}{l}\text { Activity } \\
\text { group }\end{array}$} & \multirow{2}{*}{$\begin{array}{l}\text { Types of } \\
\text { epithelial cells }\end{array}$} & \multirow{2}{*}{$\begin{array}{l}\text { Marginal } \\
\text { vacuoles }\end{array}$} & \multicolumn{2}{|c|}{ Types of follicles } & \multirow{2}{*}{$\begin{array}{l}\text { Amount of } \\
\text { colloid }\end{array}$} \\
\hline & & & Size $\left.^{1}\right)$ & Shape ${ }^{2}$ ) & \\
\hline 1 & squamous & rare & $\mathrm{ML}(\mathrm{G})$ & $\begin{array}{l}\text { from round to } \\
\text { oval, slight } \\
\text { angularity } \\
\text { often seen }\end{array}$ & very high \\
\hline \multirow[t]{2}{*}{$1-2$} & from squamous & & & & \\
\hline & to low cubic & $"$ & $m$ & $"$ & $"$ \\
\hline 2 & from low cubic to cubic & $"$ & (S) ML & $"$ & $"$ \\
\hline $2-3$ & mostly cubic & few & SML & from round to oval & relatively high \\
\hline 3 & $\begin{array}{l}\text { from cubic to high cubic, } \\
\text { loosely attached or free } \\
\text { cells are often seen }\end{array}$ & $\begin{array}{l}\text { quite } \\
\text { frequent }\end{array}$ & $\mathbf{S M}(\mathbf{L})$ & $"$ & moderate \\
\hline $3-4$ & $"$ & 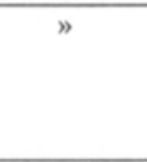 & $"$ & $\begin{array}{l}\text { about one half are } \\
\text { round or oval the } \\
\text { rest being angular } \\
\text { or elongated }\end{array}$ & $\begin{array}{l}\text { from } \\
\text { relatively low to } \\
\text { fairly high }\end{array}$ \\
\hline 4 & $\begin{array}{l}\text { from cubic to high cylind- } \\
\text { ric, occasional loosely } \\
\text { attached or free cells } \\
\text { are often seen }\end{array}$ & frequent & SML & $\begin{array}{l}\text { mostly angular, } \\
\text { flat, elongated }\end{array}$ & $"$ \\
\hline $4-5$ & $\begin{array}{l}\text { " } \\
\text { plus papillary formations } \\
\text { here and there }\end{array}$ & $\begin{array}{l}\text { very } \\
\text { frequent }\end{array}$ & $"$ & $\begin{array}{l}\text { mostly irregular, } \\
\text { epithelial cell out- } \\
\text { growths often invaded } \\
\text { into follicular lumen }\end{array}$ & $"$ \\
\hline 5 & $\begin{array}{l}\text { like } 4-5 \text {, but more } \\
\text { papillaries, often also } \\
\text { basally cituated vacuoles }\end{array}$ & $"$ & $\mathrm{SM}(\mathrm{L})$ & $\begin{array}{l}\text { irregular, epithelial } \\
\text { cell outgrowths } \\
\text { strongly invaded } \\
\text { into lumen }\end{array}$ & low \\
\hline 6 & $"$ & $"$ & $"$ & $"$ & very low \\
\hline
\end{tabular}

1) $\mathrm{S}=$ small, $\mathrm{M}=$ medium, $\mathrm{L}=$ large, $\mathrm{G}=$ giant, ( ) less fre zuent type.

2) Does not concern small follicles, which usually are round.

The percentages of epithelium (E\%), colloid (C\%), and stro$\mathrm{m}$ a $(\mathrm{S} \%)$ were estimated from each thyroid preparation in the following manner. A net prevailing morphological characteristics, into one of the activity groups described in Table 1. Groups $1-3$ were distinguished from each other mainly on the basis of the types of the epithelial cells, groups 3-5 on the basis of the types of the follicles, and groups 5-6 on the basis of the amount of colloid. The numerical value of each group is interpreted to indicate of the histological activity of the gland, eg. 1 indicating very low and 6 very high activity. The six micrographs in Fig. 2 (magnification $\times 158$ ) demonstrate the microscopical appearance of the thyroid specimens in the six main classes described in Table 1.

Fig. 2. Samples on the histological appearance of the thyroid tissue in each of the six main activity groups given in Table $1(158 \mathrm{x})$. 
constructed from a thin, transparent but quite firm plastic plate and from thin black sewing thread, was attached firmly to the lanameter (Fig. 1). Altogether 44 crossing points of the black thread of this net fell within the inner circle of the lanameter's light table. Only these points were considered, when from ten fields of vision, selected as previously described (KossiLA 1967, p. 37), the number of crossing points that met epithelial tissue, colloid, and stroma, were registered separately for each thyroidal component with a blood cell counter (Fig. 1). In order to obtain the E \%, the number of points representing epithelial tissue were calculated as a percentage of the total number of points counted for each tissue specimen. $\mathrm{C} \%$ and $\mathrm{S} \%$ were obtained in similar manner.

This method is a simplified modification of the histoquantitative method of UotiLA \& Kannas (1952), and it was developed specially for the use of the lanameter. It is very rapid (10 minutes/sample) and could be carried out with the equipment aiready available in the laboratory. Reliability was tested by estimating the E \% from 100 thyroid specimens, in which the E \% varied from 10 to 50 , by the methods of this study and that of Uotila \& Kannas. The average E \% was found to be 25.89 and 23.16, respectively, and the coefficient of correlation between the two methods 0.7 . The accuracy of the present method was considered to be sufficiently high for large scale routine studies. The E \% is high e.g. in poorly differentiated or iodine deficient thyroids.

The absolute amount of the epithelial tissue in grams per gland (Eg) was calculated from the weight of the gland using the $\mathrm{E} \%$. The Eg value is raised for instance in iodine deficiency and after treatment with goitrogens.

The statistical calculations were performed in the Computing Centre of the University of Helsinki.

\section{Results}

The present data $(\mathrm{N}=1124)$ was characterized with the following range values: carcass $7-214 \mathrm{~kg}$, thyroid weight $2.1-130.0 \mathrm{~g}$, histological activity $1-6$, FN $9.0-84.7$, E $\mu$ 2.2-22.5, Eg 0.44-98.15, E \% 14.4-88.2, C \% 4.1-85.1, S \% 0.9-14.6. Respective mean values as well as the distribution of the material according to breed and sex are given in Table 3.

Correlation study.

In order to find out whether, and to what degree: a) breed, sex, and weight of the carcass affected the weight and other characteristics of the thyroid, and b) the thyroid weight was correlated with various other characteristics of the gland, a correlation matrix (Table 2) was calculated for the entire data.

As results in Table 2 show, breed and sex were not appreciably correlated with the various thyroid characteristics. On the other hand, carcass weight correlated fairly closely with the thyroid weight (.44), histological activity (.47), and $\mathrm{E} \mu(.36)$, and to a lesser extent also with the FN (-.17), Eg (.23), S \% (.22), and $\mathrm{C} \%(-.11)$ but hardly at all with the $\mathrm{E} \%(.05)$. These results indicate that of the various thyroid characteristics, the E \% was most of all independent of the variations in the carcass weight.

Thyroid weight correlated very closely with $\mathrm{Eg}(.86)$ and fairly closely with histological activity (.37), $\mathrm{E} \mu(.40), \mathrm{E} \%(.39)$, and $\mathrm{C} \%(-.40)$ and to a lesser extent also with $\mathrm{FN}$ $(-.10)$ and $\mathrm{S} \%(.20)$. These results indicate that heavy thyroids in this data tended to be 
Table 2. Simple correlations between breed, sex, carcass weight, and thyroid characteristics $(\mathrm{N}=1124)$.

\begin{tabular}{|c|c|c|c|c|c|c|c|c|c|c|c|}
\hline \multirow[b]{2}{*}{ Variable } & \multicolumn{6}{|c|}{ Carcass Thyroid Hist. } & \multirow[b]{2}{*}{$\mathrm{E} \mu$} & \multirow[b]{2}{*}{ Eg } & \multirow[b]{2}{*}{ E \% } & \multirow[b]{2}{*}{ C \% } & \multirow[b]{2}{*}{$\mathrm{S} \%$} \\
\hline & Breed & Sex & wt. & wt. & activ. & FN & & & & & \\
\hline Breed & 1 & .07 & -.04 & -.06 & .08 & -.03 & .02 & -.03 & .01 & -.03 & .09 \\
\hline Sex & & 1 & -.12 & -.07 & .02 & .02 & .02 & -.03 & -.01 & .01 & .05 \\
\hline Carcass wt. & & & 1 & .44 & .47 & -.17 & .36 & .23 & .05 & -.11 & .22 \\
\hline Thyroid wt. & & & & 1 & .37 & -.10 & .40 & .86 & .39 & -.40 & .20 \\
\hline Hist. activity & & & & & 1 & .25 & .76 & .38 & .45 & -.52 & .43 \\
\hline FN & & & & & & 1 & .16 & .01 & .24 & -.24 & .14 \\
\hline $\mathrm{E} \mu$ & & & & & & & 1 & .46 & .50 & -.54 & .36 \\
\hline Eg & & & & & & & & 1 & .65 & -.64 & .24 \\
\hline E \% & & & & & & & & & 1 & -.98 & .44 \\
\hline C $\%$ & & & & & & & & & & 1 & -.59 \\
\hline S \% & & & & & & & & & & & 1 \\
\hline
\end{tabular}

Significance of the correlations has been tested with a formula:

$\mathrm{t}=\mathrm{r} \sqrt{\frac{(\mathrm{N}-2)}{1-\mathrm{r}^{2}}}$ (ref. Croxton \& CowDEN 1955). According to this test, all coefficients of correlation that were \pm .15 or closer are highly significant $(\mathrm{P}<0.001)$

Table 3. Numbers of breed and sex, and the weight of the carcass, characteristics of the thyroid, and consumption of iodized mineral salt mixtures on the average in various Agricultural Societies.

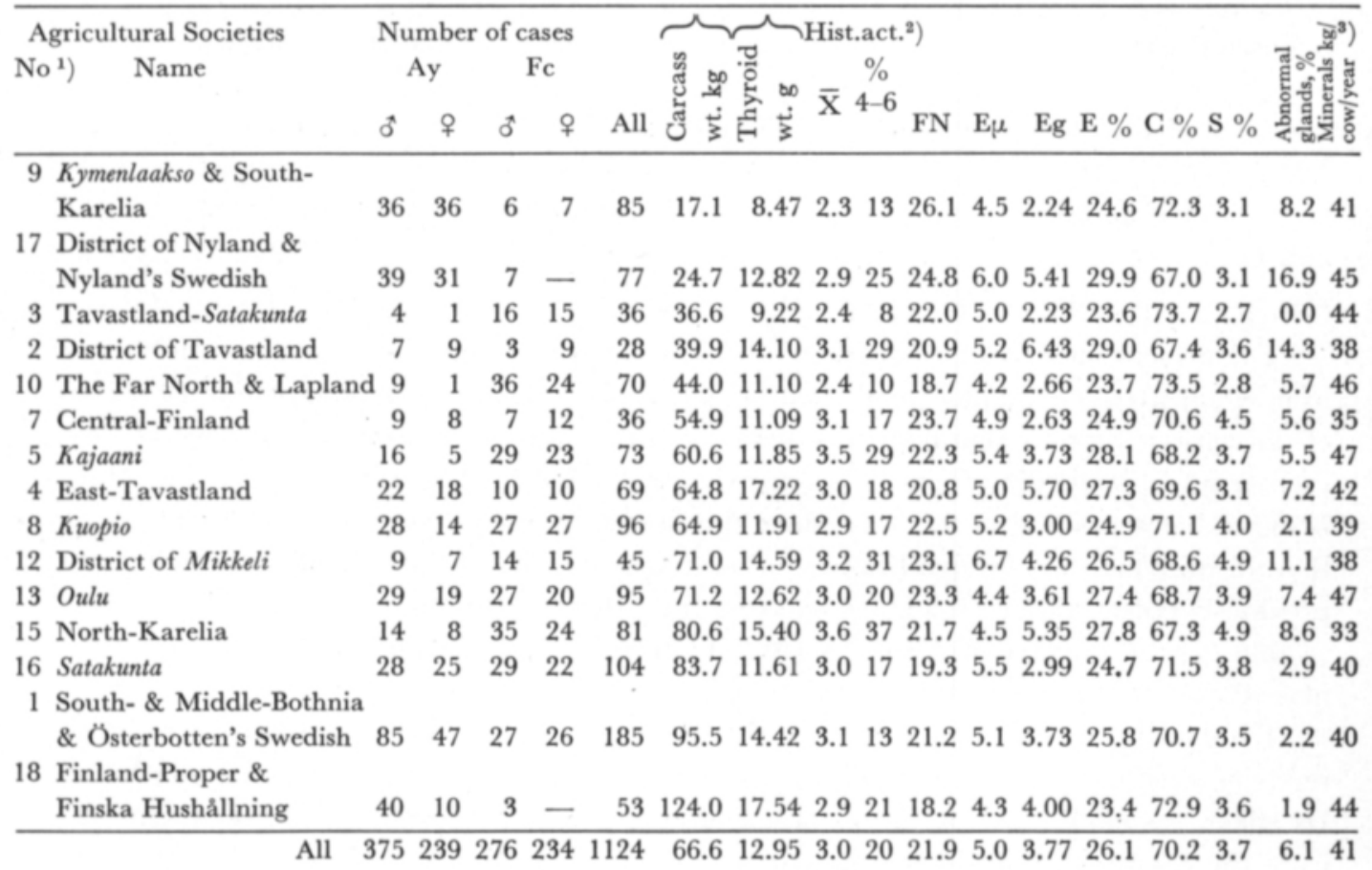

1) Geographic location of each Society is shown in Fig. 3.

2) $\overline{\mathrm{X}}=$ mean, $\% 4-6=$ percent of cases classified as $4<$.

3) Iodized mineral salt mixtures 
Table 4. Elimination of the effect of the animal's size (carcass weight) on some of the thyroid characteristics.

\begin{tabular}{|c|c|c|c|c|c|c|c|c|c|c|}
\hline \multirow{3}{*}{$\begin{array}{l}\text { Area } \\
\text { No. }\end{array}$} & \multicolumn{4}{|c|}{ Thyroid weight } & \multicolumn{4}{|c|}{ Eg } & \multicolumn{2}{|c|}{$\begin{array}{c}\text { Histological } \\
\text { activity }\end{array}$} \\
\hline & $\left.Y^{1}\right)$ & $\left.\mathrm{D}_{\mathrm{y}}{ }^{2}\right)$ & Control & $\left.\mathrm{D}_{\mathrm{c}}{ }^{3}\right)$ & $\left.\mathrm{Y}^{\mathbf{1}}\right)$ & $\left.\mathrm{D}_{\mathrm{y}}{ }^{2}\right)$ & Control & $\left.\mathrm{D}_{\mathrm{c}}{ }^{3}\right)$ & $\overline{\left.Y^{1}\right)}$ & $\left.\mathrm{D}_{\mathrm{y}}{ }^{2}\right)$ \\
\hline & & $\%$ & & $\%$ & & $\%$ & & $\%$ & & $\%$ \\
\hline 9 & 8.64 & -1.97 & 7.52 & 12.63 & 2.36 & -5.09 & 1.42 & 57.75 & 2.3 & 0.0 \\
\hline 17 & 9.30 & 37.85 & 8.20 & 56.34 & 2.58 & 109.69 & 1.45 & 273.10 & 2.4 & 12.5 \\
\hline 3 & 10.34 & -10.83 & 9.20 & 0.22 & 2.92 & -23.63 & 1.52 & 46.71 & 2.6 & -7.7 \\
\hline 2 & 10.62 & 32.76 & 9.50 & 48.42 & 3.01 & 113.62 & 1.55 & 314.84 & 2.6 & 19.2 \\
\hline 10 & 10.98 & 1.09 & 9.80 & 13.27 & 3.13 & -15.02 & 1.56 & 70.51 & 2.7 & -11.1 \\
\hline 7 & 11.93 & -7.04 & 10.65 & 4.13 & 3.43 & -23.32 & 1.63 & 61.35 & 2.8 & 10.7 \\
\hline 5 & 12.43 & -4.67 & 10.90 & 8.72 & 3.60 & 3.61 & 1.70 & 119.41 & 2.9 & 20.7 \\
\hline 4 & 12.79 & 34.60 & 11.03 & 56.12 & 3.72 & 53.23 & 1.74 & 227.59 & 3.0 & 0.0 \\
\hline 8 & 12.80 & -6.95 & 11.04 & 7.88 & 3.72 & -19.36 & 1.75 & 71.43 & 3.0 & -3.3 \\
\hline 12 & 13.33 & 9.45 & 11.25 & 29.69 & 3.89 & 9.51 & 1.82 & 134.07 & 3.0 & 6.7 \\
\hline 13 & 13.35 & -5.47 & 11.33 & 11.39 & 3.90 & -7.43 & 1.84 & 96.20 & 3.1 & -3.2 \\
\hline 15 & 14.17 & 8.68 & 11.60 & 32.76 & 4.16 & 28.61 & 1.95 & 173.36 & 3.2 & 12.5 \\
\hline 16 & 14.44 & -19.60 & 11.76 & -1.28 & 4.25 & -29.65 & 2.00 & 49.50 & 3.2 & -6.3 \\
\hline 1 & 15.47 & -6.79 & 12.20 & 18.20 & 4.59 & -18.74 & 2.15 & 73.49 & 3.4 & -8.8 \\
\hline 18 & 17.95 & -2.51 & 13.30 & 31.88 & 5.39 & -25.79 & 2.50 & 60.00 & 3.8 & -23.7 \\
\hline
\end{tabular}

1) $\mathrm{Y}=$ theoretical value obtained from the corresponding estimating equation presented in the text

2) $\mathrm{D}_{\mathrm{y}}=$ deviation of the true mean value of each area (Table 3) from $\mathrm{Y}$

3) $\mathrm{D}_{\mathrm{c}}=" n " n "$ " " " from the control

hyperepithelial, hyperactive, and poor in colloid. Histological activity correlated closely with $\mathrm{E} \mu$ (.76), fairly closely with $\mathrm{Eg}(.38), \mathrm{E} \%(.45), \mathrm{C} \%(-.52)$, and $\mathrm{S} \%(.43)$, and to a lesser extent with FN (.25); FN correlated to a lesser extent with $\mathrm{E} \mu(.16), \mathrm{E} \%$ (.24), C \% (-.24), and S \% (.14). E $\mu$ correlated fairly closely with Eg (.46), E \% (.50), C \% (-.54), and S \% (.36); Eg correlated quite closely with E \% (.65) and C \% (-.64), and $\mathrm{C} \%$ with $\mathrm{S} \%(-.59)$.

Geographic distribution of goitre.

The present data was first divided into 15 groups according to the Agricultural Society from whose area the samples were taken (Table 3 ). The mean carcass weight and the means of the various thyroid characteristics were calculated for the 15 groups. The groups were then arranged according to mean carcass weight (Table 3). The observation of the results is somewhat simplified in this way, since the weight and some other characteristics of the thyroid were found to be significantly influenced by the size of the animal. Although it was previously noted that breed and sex had very little effect on the characteristics of the thyroid (Table 2), the number of Ayrshires (Ay), Finncattle (Fc), $\delta^{\star}$, and $\phi$ in each group have, nevertheless, been given in Table 3 .

Th y r o id we i g h t. The mean thyroid weights obtained for each area are not directly comparable with each other because of the carcass weight being an interfering factor. Its effect was eliminated by means of calculating first the theoretical thyroid weight $(\mathrm{Y})$ from the equation obtained for the entire data $(\mathrm{N}=1124): \mathrm{Y}=7.147+0.087 \mathrm{X}$, in which $\mathrm{Y}=$ thyroid weight in $\mathrm{g}$ and $\mathrm{X}=$ carcass weight in $\mathrm{kg}$, and then estimating the deviation of the true mean value in percent from the theoretical one $\left(D_{y}\right)$. The results obtained this way have been presented in Table 4 . 
Another method which also was used, was the estimation of the deviations of the true mean values from the control values ( $\left.D_{c}\right)$ (Table 4 ). This method has been preferred particularly since it became evident that the rate of increase of the thyroid weight in the controls was somewhat more rapid up to $100 \mathrm{~kg}$ body weight (corresponds to carcass weight of $50 \mathrm{~kg}$, if slaughter percentage is assumed to be 50) than thereafter (Kossila 1967, p. 78).

The geographical distribution of goitre in Finland, judged by the deviation of the mean thyroid weight in each area from the control, is demonstrated in Fig. 3. It shows that the thyroid weight has been highest in areas 2,4 , and 17, somewhat raised in areas 12, 15, and 18 , only slightly raised in areas $1,5,8,9,10$, and 13 , but similar to control herd in areas 3,7 , and 16 .

E \%. The thyroidal E \% was found not to be influenced by the carcass weight (Table 2). Therefore, the regional differences can be observed as such (Fig. 4). The E \% was highest in areas 2 and 17 and lowest in areas 3, 7, 8, 9, 16, and 18. Even in the latter areas, the $\mathrm{E} \%$ has been somewhat higher than in the control herd, in which the young animals had an E \% below 20 on an average (Kossila 1967 p. 77).

$\mathrm{E}$. The thyroidal Eg value was found to be somewhat influenced by the carcass weight (Table 2). The theoretical Eg values obtained separately for each area from the regression equation based on the present data: $\mathrm{Y}=1.878+0.028 \mathrm{X}$, in which $\mathrm{Y}=\mathrm{Eg}$ and $\mathrm{X}=$ carcass weight in $\mathrm{kg}$, as well as the $\mathrm{Eg}$ values representing the control herd are given in Table 4. The theoretical Eg values obtained from the above equation are higher compared to control values (Table 4). The deviation of the Eg as a percent from the control (Fig. 5) was found to be highest in areas 2 and 17, markedly raised in areas 4 and 15 and somewhat less raised in areas 5, 12, and 13. Yet in the remaining areas, the Eg was notably higher (from $45-75 \%$ ) compared to the control values.

$\mathrm{Histological} \mathrm{activity} \mathrm{of} \mathrm{the} \mathrm{thyroid} \mathrm{was} \mathrm{found} \mathrm{to} \mathrm{be} \mathrm{influenced} \mathrm{by} \mathrm{the} \mathrm{car-}$ cass weight (Table 2). The regression equation obtained from the entire data had the form: $\mathrm{Y}=2.025+0.014 \mathrm{X}$, in which $\mathrm{Y}=$ activity class (Table 1, ) and $\mathrm{X}=$ carcass weight in $\mathrm{kg}$. The deviations of the true mean activity values from the theoretical values, obtained from the above equation, are given in Table 4. They indicate, among others, that histological activity was high in areas 2 and 5, but low in areas 10 and 18.

The present data included about $20 \%$ of cases classified histologically as 4 or higher, while no such thyroids were found in the controls. In this study activity classes 5 and 6 considered histologically definitely as abnormal. Regional incidence of abnormal thyroids is demonstrated in Fig. 6. High incidence $(10 \%<)$ was found in areas 2, 12, and 17, relatively high $(7.2-8.6 \%)$ in areas $4,9,13$, and 15 . In areas 5,7 , and 10 , incidence was $5.5-5.7 \%$. In areas $1,3,8,16$, and 18 it was rather low $(<2.9 \%)$.

$\mathrm{O}$ ther thyroid $\mathrm{characteristics}$ are considered only briefly in this connection. The highest mean FN values were found in areas 9 and 17, these data comprising very young animals, and the lowest values in areas 10,16 , and 18, the two latter data comprising rather large animals (Table 3).

The mean $\mathrm{E} \mu$ value was high in areas 12 and 17 but low in areas 10 and 18. Areal trends in $\mathrm{C} \%$ were opposite to those of $\mathrm{E} \%$. The mean S \% was highest in areas 12 and 15 but lowest in areas 3 and 10 .

Consumption of iodized $\mathrm{mineral} \mathrm{salt} \mathrm{mixt}$ ures in $\mathrm{kg} / \mathrm{cow} /$ year in the area of each Agricultural Society (Table 3) was calculated from the data made 


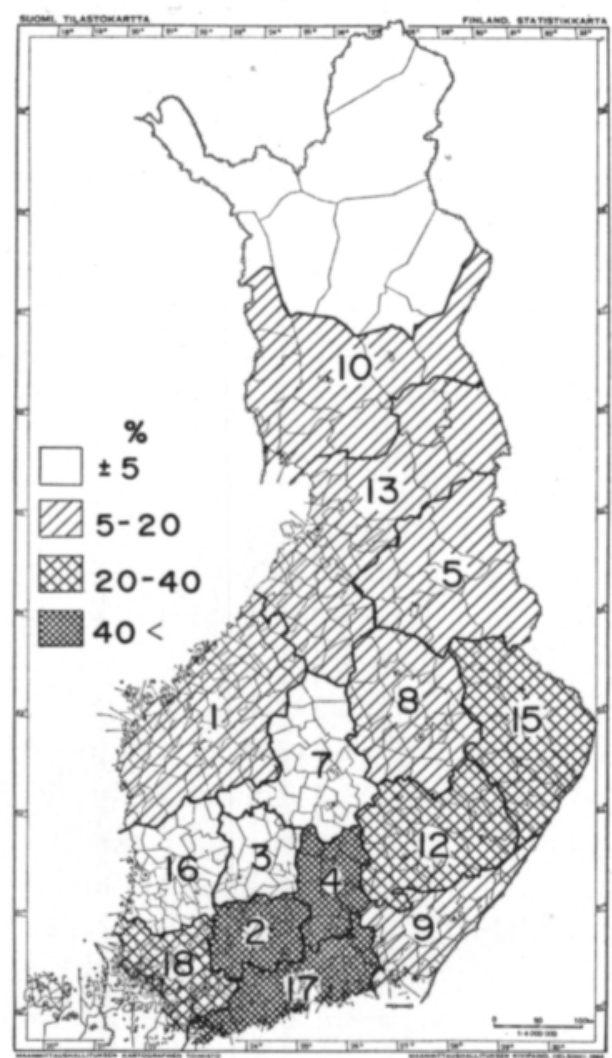

Fig. 3. Deviation of the mean thyroid weight in in percent from the control in each area. Area numbers are found in Table 3 .

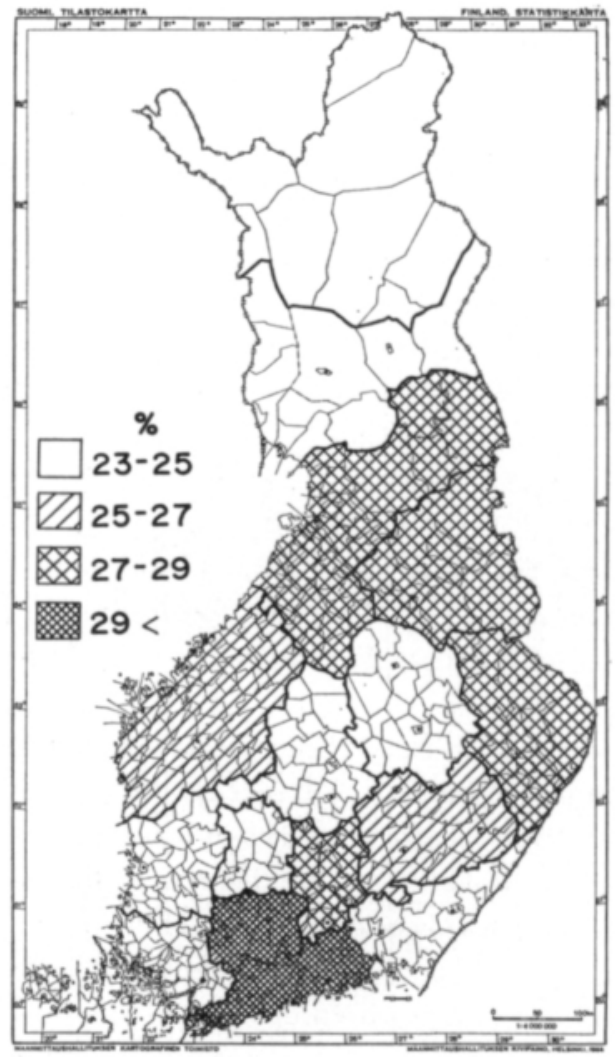

Fig. 4. Mean percentage of epithelial tissue of the thyroid (E \%) in each area.

available specially for this study by various feed factories. In this way it was possible to trace the regional distribution of $83 \%$ of the total of 43189 tons sold in Finland in 1967. Iodine in these mixtures was in the form of either potassium iodide $(0.004-0.006 \%)$ or copper iodide $(0.010 \%)$. Average consumption in the whole country was $40.8 \mathrm{~kg} / \mathrm{cow} /$ year, which is only about $1 / 3$ of the amount used in the control herd.

As values in Table 3 indicate, in the areas 5, 10, and 13, which are located in NorthFinland, and in which the indoor feeding period is relatively long, the consumption has been relatively high, while the incidence of goitre has been relatively low. On the other hand, in area 17, which is located in South-Finland, and in which the goitre incidence was found to be high, the consumption rate was also relatively high. Relatively low consumption levels in turn, were found in one nongoitrous area, 7, and in the goitrous areas 2, 12, and 15. There appeared to be a certain tendency for the percentage of the cases classified histologically as $4-6$, and particularly the S $\%$, to decrease with increasing consumption of the iodized mineral salt mixtures (Table 3). 


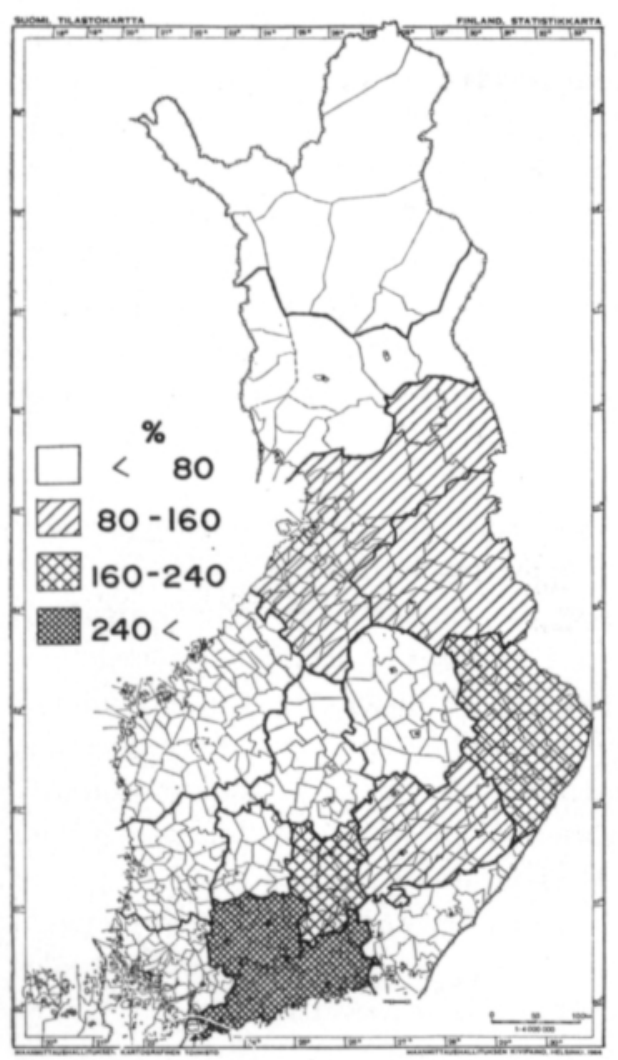

Fig. 5. Deviation of mean epithelial tissue content of the thyroid $(\mathrm{Eg})$ in percent from control in each area.

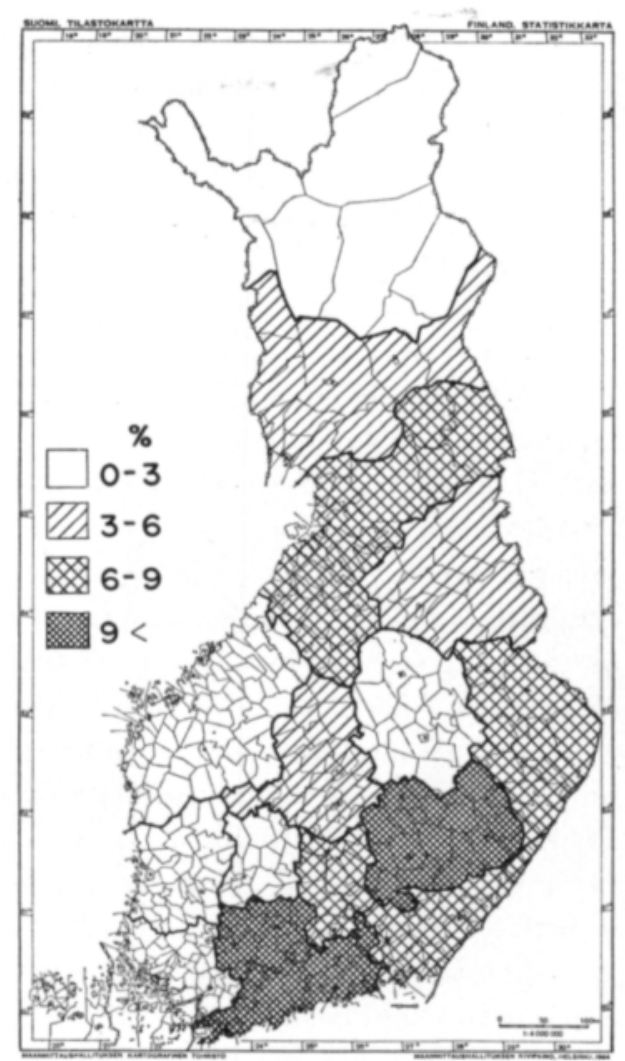

Fig. 6. Percentage of histologically abnormal thyroids in each area.

\section{Discussion}

Incidence of goitre was found to be highest in areas $2,4,12,15$, and 17, according to the extent of the rises in the weight of the thyroid, the $\mathrm{E} \%, \mathrm{Eg}$, and the percentage of histologically abnormal glands (Fig. 3-6). The percentage of histologically abnormal glands was relatively high $(7.4-8.2 \%)$ in areas 9 and 13 , and the histological activity, $\mathrm{E} \mu$, and $\mathrm{E} \%$ raised in area 5, the thyroid weights being quite normal respectively. The thyroid weight was found to be somewhat raised in areas 1 and 18, and the percentage of histologically abnormal glands fairly high (5.6-5.7) in areas 7 and 10, the other signs of goitre being either weak or missing in these areas. Relatively few histologically abnormal glands were found $(2.1-2.9 \%)$ in areas 8 and 16 , while other signs of goitre were not observable. No signs of goitre were found in area 3 with the methods used in the present study.

In this study, only the thyroids, classified histologically into activity groups $5-6$, were considered as abnormal. However, in addition to these, a few cases in the activity groups $1-2$ exhibited degenerative transformations, such a condition is rare in young animals, however. 
Unfortunately the present data lacks material from areas located near the cities Iisalmi, Savonlinna, and Hämeenlinna and from the area eastwards from Joensuu, the three latter being rated as human goitre districts. Furthermore, it would have been better from the point of view of this study if the animals had been more uniform in age.

The results of this study agree with those of Andersson (1960), who found a higher E \% in the thyroids of calves derived from Helsinki, Lahti, and Joensuu (correspond to areas 17, $2+4$, and 15 of this study) compared to those derived from Pori, Seinäjoki and Kristiina (correspond to areas 1 and 3 of this study). According to general opinion, goitre is rare in sea coast areas. However, WIERTZ (1957) found goitre even in cattle kept on the seacoast area of the Netherlands. In this study, goitre was found particularly in area 17, which is located on the coast of the Gulf of Finland.

According to several studies made in other countries, geographic distribution of goitre in cattle appears to be parallel with that in man. Similar conclusions can be drawn, if the results of the present study are compared with those obtained earlier in the investigations on human goitre in Finland (ref. Nordman 1968, p. 12-15). Furthermore, the incidence of goitre in Finland seems to be related to the iodine content in the diet. Consumption of iodized mineral salt mixtures by cattle varied somewhat in different Agricultural Societies, but not enough to explain satisfactorily the differences noted in the incidence of goitre. In the control herd, in which no histologically abnormal thyroids were found in young cattle during $1960-69$, the consumption of iodized mineral salt mixtures was three times as high as the respective value representing the whole country in 1967. It should be noted that the control herd is located in a goitrous area, 17 (Fig. 3), and that goitre was also found in this herd before the introduction of iodine prophylaxis (KossiLA 1967).

Judging by the results of this study it can be assumed that, either the distribution of the use of iodized mineral salt mixtures has not been wide enough, or that the amounts of iodine in these mixtures have not been high enough to prevent goitre in certain areas. Therefore, it is recommended that consumption of supplemental iodine should be increased considerably in areas 2, 4, 12, 15, and 17, and moderately in areas 1, 5, 7, 9, 10, 13, and 18. On the other hand, in areas 3,8 , and 16 , the intake of iodine by cattle has apparently been almost sufficient for preventing signs of goitre. Furthermore, iodine requirements are likely to rise with increasing efficiency in animal production, particularly during lactation, and also dry, pregnant cows require sufficient amounts of iodine to prevent goitre in the developing fetus.

Requirements for supplemental iodine depend on the natural content of iodine as well as on the amount of various goitrogenic factors in the feedstuffs and drinking water. Only after the amounts of supplemental iodine in the diet of dairy cattle have been markedly increased from the level used in 1967, is it possible to draw conclusions as to whether there are such areas in which goitre cannot be prevented by means of iodine prophylaxis.

\section{Su $m$ m a ry}

In 1968, thyroid glands were obtained from young dairy animals born and raised in the areas of various Agricultural Societies of Finland. Breed, sex and carcass weight were recorded for each case. The thyroids were weighed and preparations made for the histological examination. The relative proportions of epithelium (E \%), colloid (C \%) and stroma $(\mathrm{S} \%)$, and the height of the epithelial cells $(\mathrm{E} \mu)$, were estimated with histometric methods, 
and the absolute amount of epithelial tissue in grams per gland (Eg) was calculated. The relative size of the follicles (FN) was also determined. The glands were classified, on the basis of prevailing histological characteristics, into activity groups indicated by numbers from 1 (low) to 6 (high). The glands in groups 5 and 6 were considered histologically as abnormal.

The data included both Ayrshires (375 $\delta^{\star}$ and 239 o $)$ and Finncattle (276 $\delta^{\star}$ and 234 $\%$ ), and was characterized by the following mean and range values: carcass weight $66.6 \mathrm{~kg}$ (7-214), thyroid weight $12.95 \mathrm{~g}(2.1-130.0)$, E \% $26.1(14.4-88.2)$, C \% 70.2 (4.185.1), S \% 3.7 (0.9-14.6), E $\mu 5.0$ (2.2-22.5), Eg 3.77 (0.44-98.15), FN 21.9 (9.084.7), histological activity $3.0(1-6)$. Data obtained from the Ayrshire herd of the Viik Experimental Farm was used as a control material for this study.

The correlation study revealed that breed and sex had very little effect on the various thyroid characteristics. Carcass weight, on the other hand, correlated significantly with all other thyroid characteristics except the E \%.

In order to evaluate the geographic distribution of goitre the data was divided into 15 groups according to the Agricultural Society in whose area the animals were born and raised. Effect of carcass weight on the weight, $\mathrm{Eg}$, and histological activity of the thyroid was first eliminated (e.g. by calculating the deviations from the respective control values) before the 15 groups were comparable with each other.

Investigations revealed that the thyroid weight, Eg, and E \% were raised and the percentage of histologically abnormal glands was high in the Agricultural Societies of the District of Nyland \& Nyland's Swedish, the District of Tavastland, East-Tavastland, the District of Mikkeli, and North-Karelia. On the other hand, hardly any or no signs of goitre were found in the Agricultural Societies of Satakunta, Tavastland-Satakunta, and Kuopio.

Attention was also paid to the consumption of iodized mineral salt mixtures by cattle in the various Agricultural Societies. The extent of variation found in the consumption rate was not, however, large enough to explain satisfactorily the differences in the goitre incidence. Since the mean consumption rate in whole Finland in 1967 was only $1 / 3$ of that of the control herd, it is concluded that the amounts of supplemental iodine in the cattle rations should be considerably increased.

Acknowledgements. The authors greatly appreciate the valuable help received during this study from the following slaughteries: Karjakunta of Helsinki, Tampere, Kouvola, Jyväskylä and Mikkeli, Lihakunta of Kuopio, Joensuu, and Kajaani, Karjapohjola of Ylivieska and Rovaniemi, the municipal slaughteries of Helsinki, Lahti and Vaasa, Itä-Savon Osuusteurastamo of Mikkeli, Itikka of Seinäjoki, Hämeen Osuusteurastamo of Tampere, Lounais-Suomen Osuusteurastamo of Turku, Oulu Oy of Oulu, and Satakunnan Osuusteurastamo of Pori. The authors are grateful to Mrs. Lisbeth Schwanck at the Department of Forensic Medicine, University of Helsinki, and to Mrs. Aune Santamäki at the Department of Pathology, College of Veterinary Medicine, Helsinki, for making the histological preparations, and to Mr. Ture Santamäki at the latter Department for making the micrographs for this study. The authors also wish to thank the various feed factories whose information material was essential in the estimation of the consumption of tracemineralized mineral salt mixtures by the cattle in the various parts of Finland. 


\title{
REFERENCES
}

Andersson, P. 1960. Nutritional muscular dystrophy in cattle with special reference to the functional state of the thyroid. Acta Path. Microbiol. Scand. 48, suppl. 134.

Bobek, S. \& Pelczarska, A. 1963. Thiocyanate level in the serum and thyroid in cows from areas with different intensities of goitre in human beings. Nature 198: 1002. London.

Brand, N., Kathein, R. A. \& Hasis, G. 1963. Comparative study of endemic goitre in man and cattle in Israel. Acta Endocrin. 42: 21-28.

Croxton, F. E. \& Cowden, D. J. 1955. Applied general statistics. 2nd ed. xvi+843 pp. .p 722 London.

Kossin., V. 1967. On the weight and basic structural components of the thyroid in dairy cattle. Acta Agr. Fenn. 109.2.

- - 1969. On the development of the thyroid weight in the dairy herd of the Viik Experimental Farm. J. Sci. Agr. Soc. Finl. 41: 149-153.

Nordman, R. 1968. Endemic goitre in Finland in the light of thyroids of newborn in 1962-1965. Ann. Paed. 14, suppl. 28.

Stukowsky, R. J., Nemeth, S., Virsik, K. \& Podoba, J. 1960. Parallelism of incidence of human and bovine goiter in West Slovakia. Vet. Med. Praha 33: 143-154.

Uotrla, U. \& Kannas, O. 1952. Quantitative histological method of determining the proportions of the principal components of thyroid tissue. Acta Endocrin. 11: 49-60.

Wrertz, G. 1957. A study of the thyroid gland in newborn calves from different parts of the Netherlands. Meded. Landbouwhogesch. Wageningen 57: 87.

\section{SELOSTUS}

\section{TUTKIMUS STRUUMAN ESIINTYMISTIHEYDESTÄ JA ERIKOISPIIRTEISTÄ NAUDALLA SUOMEN ERI ALUEILLA}

\author{
Vappu Kossila, Ulla-ritta Lehtonen, Majja-leena Sulkinoja ja Ritva MyllymaA
}

\section{Helsingin yliopiston kotieläintieteen laitos}

Kevättalvella 1968 kerättiin yhteensä 1124 kilpirauhasnäytettä nuorista naudoista eri puolilta Suomea. Aineiston keruussa huomioitiin eläinten rotu, sukupuoli, ruhopaino ja kotikunta. Kilpirauhaset punnittiin ja niistä valmistettiin preparaatit histologista tutkimusta varten. Jokaisesta näytteestä määritettiin histometrisesti epiteelisolukon (E \%), kolloidin (C \%), ja sidekudoksen (S \%) suhteelliset osuudet, epiteelisolujen korkeus $(\mathrm{E} \mu)$ ja follikelien suhteellinen koko (FN). Lisäksi laskettiin epiteelisolukon määrä grammoina rauhasta kohden (Eg). Kilpirauhaset ryhmiteltiin vallitsevien histologisten ominaisuuksiensa perusteella ns. aktiviteettiluokkiin, joita karakterisoitiin numeroin 1:stä (alhainen) 6:teen (korkea). Luokkiin 5 ja 6 ryhmiteltyjä pidettiin selvästi epänormaaleina. Tutkimuksessa käytettiin kontrolliaineistona Viikin opetus- ja koetilan nuorkarjasta kerättyä kilpirauhasmateriaalia.

Tutkittavassa aineistossa oli mukana 375 đ๋ ja 239 ㅇ Ayrshirerodun ja 276 đ̊ ja 234 ㅇ Suomen Karjan yksilöä. Koko aineistoa kuvaavien eri tekijöiden keskiarvot ja vaihtelurajat olivat seuraavat: ruhopaino $66.6 \mathrm{~kg}$ (7-214), kilpirauhaspaino $12.95 \mathrm{~g}(2.1-130.0)$, E \% 26.1 (14.4 - 88.2), C \% 70.2 (4.1-85.1), S \% 3.7 (0.9-14.6), E $\mu 5.0$ (2.2-22.5), Eg 3.77 (0.44-98.15), FN 21.9 (9.0-84.7), histologinen aktiviteetti $3.0(1-6)$.

Koko aineiston käsittäneessä vuorosuhdeanalyysissä kävi mm. ilmi, että rodulla ja sukupuolella ei ollut mainittavaa vaikutusta kilpirauhasen ominaisuuksiin. Sensijaan ruhopaino vaikutti merkittävästi kaikkiin muihin kilpirauhasominaisuuksiin paitsi E \%:iin. Tästä syystä ruhopainon vaikutus eliminoitiin ennenkuin ryhdyttiin vertailemaan struuman esiintymistiheyttä ja piirteitä eri alueilla. Tässä mielessä otettiin tarkasteltaviksi erityisesti kilpirauhasen paino, Eg, ja histologinen aktiviteetti, joita mm. verrattiin kontrolliaineistoon. Tutkimuksen kannalta olisi tietenkin ollut edullisempaa, että eläinten koko olisi vaihdellut vähemmän.

Tutkimusaineiston alueellinen jako suoritettiin noudattamalla maanviljelysseurojen rajoja. Uudenmaanläänin \& Nylands Svenska'n, Hämeenläänin, Itä-Hämeen, Mikkelinläänin ja Pohjois-Karjalan mvs:n 
alueilta löydettiin keskim. painavimmat kilpirauhaset samalla kun E \%, Eg ja histologisesti epänormaalien kilpirauhasten lukumäärä oli korkea. Toisaalta Satakunnan, Hämeen-Satakunnan ja Kuopion mvs:n alueilta tavattiin tuskin lainkaan ko. struumaoireita.

Kymenlaakson \& Etelä-Karjalan mvs:n ja Oulun talousseuran alueilta löytyi n. 8 \% ja Keski-Suomen, Kajaanin, sekä Perä-Pohjolan \& Lapin mvs:n alueilta n. 6 \% histologisesti epänormaaleja rauhasia. Varsinais-Suomen \& Finska Hushållning'in ja Etelä \& Keski-Pohjanmaan \& Österbåttens Svensk'an mvs:n alueilla kilpirauhaspaino oli hiukan kohonnut, mutta epänormaalien rauhasten määrä oli alhainen $(1.9-2.2 \%)$.

Tutkimuksessa tarkasteltiin myös jodisoitujen kivennäissuolaseosten kulutusta maanviljelysseuroittain, mikä v. 1967 oli keskimäärin vain 1/3 kontrolliin verrattuna. Ehkäpä osittain tästä syystä jodisoitujen suolojen käytön ei todettu liittyvän kiinteästi struuman esiintymistiheyteen, joskin joitakin tendenssejä oli havaittavissa. Tulosten tarkastelussa päädyttiin siihen, että jodisoitujen kivennäissuolaseosten käyttöä olisi huomattavasti nykyisestään lisättävä erityisesti niillä alueilla joilla struumaa esiintyy eniten. 